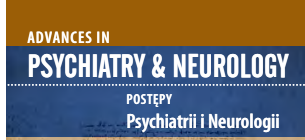

Correspondence to/Adres do korespondencji:

Karol Womperski

Faculty of Medicine

Wrocław Medical University

5 J. Mikulicza-Radeckiego St.

50-345 Wroclaw, Poland

e-mail: karolwomperski@gmail.com

Submitted/Otrzymano: 13.07.2020

Accepted/Przyjęto do druku: 22.01.2021

\section{Comorbidity of obsessive-compulsive disorder and anorexia nervosa - diagnostic difficulties: a case study of a 14-year old girl} Współwystępowanie zaburzeń obsesyjno-kompulsyjnych i anoreksji, trudności diagnostyczne - opis przypadku 14-letniej pacjentki

\author{
Karol Womperski $\mathbb{D}$, Justyna Woźniak (D) \\ Faculty of Medicine, Wrocław Medical University, Wrocław, Poland \\ Wydział Lekarski, Uniwersytet Medyczny we Wrocławiu, Polska
}

\begin{abstract}
Purpose: The objective of this paper is to present the comorbidity of anorexia nervosa (AN) and obsessive-compulsive disorder $(\mathrm{OCD})$ and to note the need for caution during the diagnostic process.

Case description: We present a case of a 14-year old girl raised in a reconstructed family. The primary diagnosis was AN, which was changed to OCD in the course of hospitalisation. Symptoms of OCD and AN occurred in close time proximity and involved excessive focus on appearance, beautifying rituals disrupting circadian rhythm, rigid behaviours, school absence, and social isolation. In further therapy, schizotypal personality disorder was suspected. Pharmacotherapy involved SSRI drugs: sertraline followed by fluoxetine.

Comment: OCD has a complex aetiology and a chronic course. However, proper management allows obtaining satisfactory control and enables the patient to function in society. The focus on anorexia in the diagnostic process can distract attention from the underlying disorders.
\end{abstract}

Key words: anorexia nervosa, obsessive-compulsive disorder, comorbidity, case study.

\title{
Streszczenie
}

Cel: Celem pracy jest przedstawienie problemu współwystępowania anoreksji (AN) i zaburzeń obsesyjno-kompulsyjnych (OCD) oraz zwrócenie uwagi na potrzebę ostrożności w procesie diagnostyki anoreksji.

Opis przypadku: Przedstawiono przypadek 14-letniej pacjentki wychowywanej w rodzinie rekonstruowanej. Dziewczynka została przekazana $\mathrm{z}$ oddziału pediatrii na oddział psychiatrii dzieci i młodzieży z rozpoznaniem $\mathrm{AN}(\mathrm{BMI}=13,98)$. W trakcie hospitalizacji zdiagnozowano OCD. Objawy OCD i AN wystąpiły w niedużym odstępie czasu lub jednocześnie i obejmowały głównie nadmierną koncentrację na wyglądzie oraz rytuały pielęgnacyjne powodujące desynchronizację dobową, usztywnienie zachowań, absencję szkolną i izolację społeczną. Pacjentka kontynuowała terapię na oddziale dziennym, następnie w poradni, gdzie wysunięto podejrzenie schizotypowych zaburzeń osobowości (SPD). W toku farmakoterapii stosowano leki z grupy SSRI - początkowo sertralinę, następnie fluoksetynę.

Komentarz: OCD jest schorzeniem o złożonej etiologii i przewlekłym przebiegu. Niemniej prawidłowe rozpoznanie i terapia umożliwiają jego kontrolę i pozwalają na funkcjonowanie pacjentów w społeczeństwie. Skupiając się w procesie diagnozy na anoreksji, można pominąć zaburzenie leżące u podstaw.

Słowa kluczowe: anoreksja, zaburzenia obsesyjno-kompulsyjne, współwystępowanie, opis przypadku. 


\section{PURPOSE}

Obsessive-compulsive disorder (OCD) is quite a common psychological disorder, at the basis of which lie intrusive thoughts (obsessions) and obligatory actions (compulsions). Obsessions are recurring unpleasant and sad ideas and impulses, stereotypical in nature, against the patient's will, causing the patient's resistance yet still perceived by them as their own. Compulsions are ritual behaviours whose goal is to minimise the risk of occurrence of the undefined and very unlikely event that could - in the patient's opinion - occur if they ceased to perform a certain task. They can also evince the need to keep perfect order, cleanliness, and symmetry in arranging objects, or a constraint to collect and amass different items. An attempt to resist performing a certain task results in anxiety, fear, and discomfort for the patient [1]. The disorder occurs in $2-3 \%$ of the general population and $1-3 \%$ of children and adolescents [2]. However, some sources suggest that women are slightly more susceptible to this disorder. OCD is considered to appear equally often in men and women, although the situation is converse among children. Peak incidence is observed in childhood and adolescence $[1,3]$. Note that it is difficult to define the beginning of the disease. Does it begin with the first obsessive thoughts or when the normal functioning of the patient is disrupted? Because of its chronic nature, OCD can cause impairment in everyday functioning. However, many patients can adapt to this state and seek help only if the symptoms exacerbate [1].

Anorexia nervosa (AN) is an eating disorder consisting in the pursuit of the severe reduction of body mass, significantly below the standards established for a specified age and height. It is accompanied by a negative perception of self-appearance, perceiving oneself as obese, and by the fear of gaining weight. The prevalence of AN is $0.5-1 \%$ among adolescents and $0.4-0.8 \%$ among adults. The disease occurs 10-20 times more often in females [2]. The highest risk of developing the disorder is at the age of between 14 and 18 [1].

This paper presents a case of a patient who was admitted to the hospital with a primary diagnosis of AN and discharged with a diagnosis of OCD. Both of these disorders may coexist. In $20-50 \%$ of patients with AN, OCD was also diagnosed during the lifetime and in $5-10 \%$ of patients with OCD, anorexia was identified [4]. Currently, comorbid eating disorders (of any subtype) are diagnosed in $1-10 \%$ of patients with OCD [5]. It is worth adding that there are some similarities between the abovementioned conditions (intrusive and fearful thoughts, compulsive need to perform rituals to reduce the level of anxiety and the intensity of obsessions). In $\mathrm{AN}$, the behaviours focus on reducing
CEL

Zaburzenia obsesyjno-kompulsyjne (OCD), niegdyś nazywane nerwicą natręctw, są dość częstym zaburzeniem psychicznym, którego istotą są natrętne myśli (obsesje) oraz przymusowe czynności (kompulsje). Obsesje to nawracające wyobrażenia, idee, impulsy pojawiające się w sposób stereotypowy, wbrew woli pacjenta, nieprzyjemne, przykre, budzące jego sprzeciw, jednak mimo to postrzegane jako własne. Kompulsjami nazywamy rytualne zachowania mające zwykle na celu zminimalizowanie ryzyka często bliżej nieokreślonego i mało prawdopodobnego zdarzenia, które według pacjenta mogłoby wystąpić, gdyby zaniechał danej czynności. Mogą także przejawiać się $\mathrm{w}$ potrzebie utrzymywania nienagannego porządku, czystości, symetrii w ułożeniu rzeczy czy też $\mathrm{w}$ przymusie zbierania i gromadzenia przedmiotów. Próba sprzeciwu względem wykonywania czynności natrętnych wiąże się z wystąpieniem lęku, obaw i dyskomfortu u pacjenta [1]. Zaburzenie to dotyka 2-3\% populacji ogólnej oraz $1-3 \%$ dzieci i młodzieży [2]. OCD uznaje się za zaburzenie występujące równie często u mężczyzn, jak i kobiet, aczkolwiek niektóre źródła podają, że kobiety są nieznacznie bardziej podatne na to zaburzenie, natomiast wśród dzieci sytuacja kształtuje się odwrotnie - szczyt zachorowań przypada na okres dzieciństwa i dojrzewania [1,3]. Warto dodać, że trudno zdefiniować początek choroby - czy jest nim moment pojawienia się pierwszych myśli natrętnych, czy też okres, w którym dochodzi do zaburzeń funkcjonowania. OCD może powodować trudności w aktywności życiowej ze względu na chroniczną naturę choroby, jednak wielu pacjentów potrafi adaptować się do niej, szukając pomocy dopiero w sytuacji znacznego nasilenia się objawów [1].

Anoreksja (AN), inaczej jadłowstręt psychiczny, to zaburzenie odżywiania polegające na dążeniu do maksymalnego ograniczenia masy ciała, znacznie poniżej norm przyjętych dla danego wieku i wzrostu. Towarzyszy mu nieprawidłowa ocena własnego wyglądu, postrzeganie siebie jako osoby otyłej i lęk przed przybraniem na wadze. Rozpowszechnienie anoreksji wśród nastolatków wynosi $0,5-1 \%$, a wśród osób dorosłych $0,4-0,8 \%$. Choroba $10-20$ razy częściej występuje u płci żeńskiej [2]. Okres największej zapadalności to przedział wiekowy pomiędzy 14. a 18. rokiem życia [1].

W poniższej pracy chcielibyśmy przedstawić przypadek pacjentki, która została przyjęta do szpitala $\mathrm{z}$ rozpoznaniem wstępnym jadłowstrętu psychicznego, a zakończyła hospitalizację z rozpoznaniem OCD. Oba te zaburzenia mogą współwystępować: u 20-50\% chorych z AN w ciągu całego życia stwierdzano również OCD, a u 5-10\% z OCD stwierdzano AN [4]. Aktualnie współtowarzyszące zaburzenia odżywiania (bez rozróżnienia na poszczególne typy) stwierdza się u 1-10\% chorych z OCD [5]. Warto dodać, że istnieją podobieństwa między powyższymi schorzeniami, które obejmują natarczywe, lękowe myśli, a także kompulsyjną potrzebę wykonywania rytuałów mających na celu obniżenie poziomu lęku i natężenia obsesji. W przypadku 
the amount of consumed food to obtain desired figure and low body mass. In OCD, they are more general and diverse [6].

The purpose of the case study is to present the problem of comorbidity of eating disorders and OCD, and, most importantly, to note the need for caution in the diagnostic process of anorexia. The case below proves that anorexia may be not the only problem.

\section{CASE DESCRIPTION}

In November 2017, a 14-year old girl, a student of junior high school, came to the admission room of a multi-specialist hospital in Wrocław with her mother and stepfather. The anamnesis revealed a reluctance to ingest food for about six months, significant body mass loss (7 kg) over the last four weeks, progressive social isolation, excessive focus on appearance, hours-long beautifying rituals at night, retardation, and repeating the activities. These behaviours resulted in school avoidance and the occurrence of symptoms (circadian rhythm disturbance and irregular emmenia). The patient was raised in a reconstructed family. Her parents divorced soon after her birth. She stayed in her mother's care. She had two step-siblings. She had been under a dermatologist's care for several years. Skin lesions in the form of juvenile acne (which according to the patient were the reason for diet modifications) were treated with Tetralysal and topical medicaments. During the first appointment with a psychiatrist in October, sertraline $25 \mathrm{mg}$ /day was prescribed. The patient refused to participate in psychotherapy. After psychiatric consultation in the admission room, the girl was admitted to the Paediatric Ward to inhibit further weight loss.

On admission to the ward, the patient was apathetic and significantly underweight $-39 \mathrm{~kg}, 167 \mathrm{~cm}$ height, $\mathrm{BMI}=13.98(<3 \mathrm{cc})$. Laboratory tests revealed elevated amylase, total cholesterol, albumins, enlargement of liver, pancreas and kidneys with obliteration of cortical-medullar differentiation (in USG). During a oneweek stay in the ward, a high calorific diet and oral specialised nutritional preparations were administered, which resulted in a mass gain of $2.6 \mathrm{~kg}$. The patient was transferred to the Psychiatric Ward for Children and Adolescents. The review of her mental status on admission revealed unaltered awareness, undisturbed autoand allopsychic orientation, unspontaneous, logical contact, indifferent mood, pale and appropriate affect. The structure and process of thought were appropriate. Sleep and appetite remained disturbed. Life activity was restricted. At the beginning of her stay in the ward, the patient isolated herself, was preoccupied with beautifying rituals, and assumed bizarre poses, with inadequate facial expression and gestures (irritable and plaintive). She did not have an insight into her disease. She
AN zachowania te koncentrują się na zmniejszeniu ilości spożywanego pokarmu oraz uzyskaniu pożądanej sylwetki i niskiej wagi, podczas gdy w OCD mają bardziej ogólny i zdywersyfikowany charakter [6].

Celem pracy jest przedstawienie problemu współwystępowania zaburzeń odżywiania i OCD, a co najważniejsze - zwrócenie uwagi na potrzebę ostrożności w procesie diagnostyki anoreksji, gdyż, jak potwierdza poniższy przypadek, nie musi ona być jedynym problemem.

\section{OPIS PRZYPADKU}

Dziewczyna, 14 lat, uczennica drugiej klasy gimnazjum, zgłosiła się w listopadzie 2017 r. wraz z matką i ojczymem na izbę przyjęć szpitala wielospecjalistycznego we Wrocławiu. W wywiadzie odnotowano niechęć do przyjmowania pokarmów od około pół roku, znaczny spadek masy ciała - $7 \mathrm{~kg} \mathrm{w}$ ciągu ostatnich czterech tygodni, postępującą izolację społeczną, nadmierną koncentrację na wyglądzie, wielogodzinne rytuały pielęgnacyjne $\mathrm{w}$ porach nocnych, spowolnienie, powtarzanie pewnych czynności. Skutkiem tych zachowań była absencja szkolna oraz objawy w postaci zaburzeń rytmu dobowego i nieregularnych miesiączek. Pacjentka była wychowywana $\mathrm{w}$ rodzinie rekonstruowanej, rodzice rozstali się niedługo po jej urodzeniu, została pod opieką matki, miała dwoje przyrodniego rodzeństwa. Była pod opieką dermatologa od kilku lat ze względu na zmiany skórne o charakterze trądziku młodzieńczego (którymi pacjentka tłumaczyła modyfikacje diety) leczone Tetralysalem oraz preparatami miejscowymi. W październiku odbyła się pierwsza wizyta u psychiatry w poradni, zalecono sertralinę $25 \mathrm{mg} /$ dobę. Pacjentka odmawiała uczestnictwa w psychoterapii. Po konsultacji psychiatrycznej na izbie przyjęć pacjentkę skierowano na oddział pediatryczny $\mathrm{w}$ celu zatrzymania dalszego spadku wagi.

Podczas przyjęcia na oddział pediatryczny pacjentka była spowolniała i apatyczna. Miała znaczny niedobór masy ciała - ważyła $39 \mathrm{~kg}$ przy wzroście $167 \mathrm{~cm}$, $\mathrm{BMI}=13,98(<3 \mathrm{cc})$. W wynikach badań laboratoryjnych stwierdzono zwiększone stężenie amylazy we krwi, cholesterolu całkowitego, albumin, w USG zaobserwowano powiększenie wątroby, trzustki i nerek z zatarciem zróżnicowania korowo-rdzeniowego. Podczas tygodniowego pobytu na oddziale włączono dietę wysokokaloryczną, doustne specjalistyczne preparaty żywieniowe, uzyskując przyrost masy ciała na poziomie $2,6 \mathrm{~kg}$. Pacjentkę przekazano na oddział psychiatryczny dla dzieci i młodzieży. Przy przyjęciu odnotowano niezaburzoną świadomość oraz orientację auto- i allopsychiczną, kontakt logiczny, nastrój obojętny, afekt bladawy, dostosowany. Tok i struktura myślenia były prawidłowe. Sen i apetyt pozostawały zaburzone, aktywność życiowa była ograniczona. Pacjentka na początku pobytu na oddziale nie nawiązywała spontanicznego kontaktu, izolowała się, była pochłonięta 
attended meetings with a psychologist and participated in family consultations.

Sertraline $50 \mathrm{mg} /$ day was prescribed. Over time, fewer bizarre and inadequate behaviour episodes were observed, with improvement in activities and consumed meals, less anxiety, and less irritability. She improved her body mass gradually (maximal body mass at the ward was $44.24 \mathrm{~kg}$ ). Compulsive behaviours still occurred but were less severe. She was more willing to spend time with her peers, attended school and therapeutic activities. On discharge, the girl was in stable mental condition, with appropriate affect and normal psychomotor drive.

After the discharge, the patient continued the treatment in the day ward for 1.5 months. The attention was paid to how perfect she was in doing her homework, to her exaggerated accuracy, to how she corrected her notes, and to her excessive looking in the mirror. The girl did not report any intrusive thoughts. Bizarre behaviours, unnatural facial expression, and inadequate gestures were still observed. She tried to prove her superiority, was uncritical, and not aware of her disease. Sleep and appetite were normal. The treatment with sertraline was continued. Eventually, the patient was discharged with the diagnosis of OCD (F42). Schizotypal personality disorder (SPD; F21) was suspected. On discharge, the girl was in stable mental condition, cooperative, with complete insight into the disease and a positive attitude towards the process of treatment.

During her stay at the stationary and day ward, she underwent family therapy, individual therapy, occupational therapy in the form of cinema therapy, and canine-assisted therapy.

Afterwards, the treatment was carried on for 1.5 years in an outpatient clinic with the main diagnosis of OCD (F42) and a coexisting diagnosis of unspecified personality disorder (F60.9). The condition of the patient did not change significantly. In March 2019, the patient ceased taking medications and participating in psychotherapy. She claimed that she no longer needed the treatment. During the visit, her affect was inappropriate and cause-and-effect thinking was disturbed. She was aggressive towards her mother and used bizarre and inadequate language. When asked for the reason for aggression, she said she "did not want to be like a squash on a perch or a carrot in the ground" She claimed that she did not want to have a relationship with her parents because she "wanted to have fun".

Nine months later, she voluntarily came for a visit, expressing greater insight into her disorder. The treatment was changed to fluoxetine $10 \mathrm{mg} /$ day. During a visit in January 2020, she expressed the need to meet with a psychologist. The girl was excessively focused on studying, had high expectations at school, and abandoned other rytuałami pielęgnacyjnymi, przyjmowała dziwne pozy, cechowała się nieadekwatną mimiką i gestami, drażliwością i płaczliwością. Nie miała wglądu we własną chorobę.

$\mathrm{W}$ farmakoterapii zastosowano sertralinę $\mathrm{w}$ dawce 50 $\mathrm{mg} /$ dobę. W toku hospitalizacji obserwowano mniej zachowań dziwacznych i niedostosowanych, poprawę w zakresie aktywności i spożywania posiłków, mniejsze nasilenie lęku i drażliwości. Stopniowo zwiększała się jej masa ciała (maksymalna masa ciała podczas pobytu na oddziale: 44,24 kg). Obserwowano nadal, choć mniej nasilone, zachowania kompulsyjne. Chętniej spędzała czas z rówieśnikami, uczęszczała na zajęcia szkolne i terapeutyczne. W chwili wypisu dziewczyna była w nastroju wyrównanym, afekt był dostosowany, napęd psychoruchowy pozostawał w normie, nie prezentowała objawów psychotycznych, negowała obecność myśli i tendencji samobójczych.

Po wypisie ze szpitala pacjentka kontynuowała leczenie na oddziale dziennym przez półtora miesiąca. Nadal występowały dziwaczne zachowania, nienaturalna mimika twarzy, niedostosowane gesty. Nastolatka nie zgłaszała myśli natrętnych. Sen i apetyt były prawidłowe. Prezentowała postawę wyższościową, brak krytycyzmu i poczucia choroby. Zwrócono także uwagę na perfekcjonizm w wykonywaniu zadań szkolnych, nadmierną dokładność, poprawianie notatek, przeglądanie się w lustrach. Utrzymano leczenie sertraliną. Ostatecznie pacjentkę wypisano z rozpoznaniem zaburzeń obsesyjno-kompulsyjnych (F42). Wysunięto podejrzenie schizotypowego zaburzenia osobowości (F21). Przy wypisie pacjentka była $\mathrm{w}$ stabilnym stanie psychicznym, współpracująca, opisywano pełny wgląd w chorobę oraz pozytywne nastawienie do procesu leczenia.

W trakcie pobytu na oddziale stacjonarnym i dziennym jednocześnie prowadzona była terapia rodzin, terapia indywidualna, terapia zajęciowa $\mathrm{w}$ postaci filmoterapii oraz dogoterapia.

Następnie przez półtora roku leczenie było kontynuowane $\mathrm{w}$ trybie ambulatoryjnym, $\mathrm{z}$ rozpoznaniem zasadniczym zaburzeń obsesyjno-kompulsyjnych (F42) oraz rozpoznaniem wspólistniejącym - zaburzeń osobowości BNO (bliżej nieokreślone, F60.9). Stan pacjentki nie ulegał większym wahaniom. W marcu 2019 r. pacjentka przestała brać leki i odmówiła spotkań z psychologiem, twierdząc, że nie potrzebuje terapii. W trakcie wizyty afekt był niedostosowany, zaburzone było myślenie przyczynowo-skutkowe, pacjentka prezentowała agresywną postawę $\mathrm{w}$ stosunku do matki, posługiwała się dziwacznymi i nieadekwatnymi wyrażeniami - zapytana, dlaczego jest agresywna, odpowiedziała: „ponieważ nie chcę być jak kabaczek na grzędzie albo marchewka w ziemi", twierdziła, że nie chce mieć relacji z rodzicami, ponieważ „chce się bawić”.

Dziewięć miesięcy później zgłosiła się na wizytę z własnej woli. Wykazywała większy wgląd w zaburzenie niż dotychczas. Leczenie zmieniono na fluoksetynę 10 $\mathrm{mg}$ /dobę. W styczniu 2020 r. w trakcie wizyty wyraziła potrzebę spotkania z psychologiem. Nastolatka była nadmiernie skoncentrowana na nauce, bardzo stresowały ją zwiększone wymagania $\mathrm{w}$ liceum, rezygnowała $\mathrm{z}$ innych 
activities to focus on schoolwork. The dose of fluoxetine was increased to $20 \mathrm{mg} /$ day.

In March 2020, the patient was in a good mental condition. She attended therapy and spent more time with her peers. She planned relocation to her father due to recurring episodes of depression in her mother and difficulties in communication with her. Further treatment with fluoxetine $20 \mathrm{mg} /$ day was advised.

\section{COMMENT}

OCD often co-occurs with eating disorders in the form of AN. The relation between these two disorders is not quite clear. Some theories state that both illnesses result from genetic factors and manifest as a desire to take control (over the environment and the surrounding in OCD, and the patient's own body in $\mathrm{AN})$, and rigidity $[4,5]$. According to others, OCD occurs in the course of $\mathrm{AN}$ as a reflection of patterns of behaviour and thoughts concerning oneself in the external environment. AN could also be a form of OCD beginning in adolescence [7].

In the patient referred to above, the disruption in functioning (resulting in absence from school) began about a year before she sought professional help. In the beginning, the most emphasis was put on her eating disorder, which was obviated upon her stay in the psychiatric ward and the psychiatric day ward. However, the compulsions were still present. In the opinion of a psychologist, the changing course of the disorder diagnosed as an eating disorder was due to a manifestation of the need to take excessive control over the patient's surroundings and body resulting from the superior idea of keeping the desired appearance (due to her skin condition).

The differential diagnosis of AN consists of depressive disorders, reactive schizophrenia with food rejection, and somatic diseases, such as thyroid functioning disorders, Addison's disease, gastroenteritis, hepatitis, Crohn's disease, pituitary gland failure, systemic diseases, cancers, especially central nervous system cancers of the subthalamus and the third ventricle. AN symptoms might also be triggered by medications and psychoactive agents, in particular amphetamine and cocaine derivatives, and nicotine. The symptoms of the patient (severely decreased body mass, body image disturbance, reluctance to ingest food) and anamnesis were typical enough to primarily set the diagnosis of AN. OCD should be differentiated from anxiety disorders, eating disorders, especially AN, depression disorders, body dysmorphic disorder, autism spectrum disorders, addictions, psychotic disorders, tic disorders, and Tourette's syndrome.

It should be emphasised that $\mathrm{AN}$ is listed among the disorders in the differential diagnosis of OCD, which zajęć na rzecz obowiązków szkolnych. Zwiększono dawkę fluoksetyny do $20 \mathrm{mg} /$ dobę.

W marcu 2020 r. pacjentka była w dobrej formie psychicznej, uczęszczała na terapię, spędzała więcej czasu z rówieśnikami, planowała przeprowadzkę do ojca ze względu na nawracające epizody depresji u matki i trudności $\mathrm{w}$ porozumieniu się $\mathrm{z}$ nią. Zalecono kontynuację leczenia fluoksetyną $20 \mathrm{mg} /$ dobę.

\section{KOMENTARZ}

OCD często współwystępują z zaburzeniami odżywiania w postaci AN. Relacja między tymi rozpoznaniami nie jest do końca zrozumiała. Niektórzy autorzy twierdzą, że są to choroby mające wspólne źródło w czynnikach genetycznych i przejawiają się chęcią przejęcia kontroli (w OCD nad środowiskiem i otaczającym światem, w AN - nad swoim ciałem) oraz sztywnością $[4,5]$. Zdaniem innych OCD przejawia się w toku anoreksji jako przełożenie schematów postępowania i myślenia dotyczących własnej osoby na środowisko zewnętrzne. AN może być również formą OCD mającą swój początek w okresie nastoletnim [7].

U opisywanej pacjentki zaburzenia funkcjonowania (przekładające się na absencję szkolną) rozpoczęly się około roku przed pojawieniem się w szpitalu. Początkowo największą uwagę zwracały zaburzenia odżywiania, które po pobycie pacjentki na oddziale stacjonarnym i dziennym zmniejszyły się, jednak objawy kompulsyjne wciąż się utrzymywały. Zgodnie z opinią psychologa zmieniający się z biegiem hospitalizacji obraz choroby, diagnozowany w kierunku zaburzeń odżywiania, można rozumieć jako manifestację nasilonej potrzeby kontroli nad otoczeniem i własnym ciałem - podyktowaną ideą nadwartościową związaną $\mathrm{z}$ utrzymaniem pożądanego wyglądu (zahamowaniem choroby skóry).

W diagnostyce różnicowej AN należy wziąć pod uwagę zaburzenia depresyjne, schizofrenię reaktywną z odmową jedzenia oraz takie choroby somatyczne, jak zaburzenia czynności tarczycy, choroba Addisona, stany zapalne żolądka i jelit, zapalenia wątroby, choroba Crohna, niewydolność przysadki, choroby układowe, nowotwory, szczególnie nowotwory OUN okolicy podwzgórza i trzeciej komory mózgu. Objawy AN mogą również wywoływać leki i środki psychoaktywne, zwłaszcza pochodne amfetaminy i kokainy, oraz nikotyna. U opisywanej pacjentki objawy (znacznie obniżona masa ciała, zaburzony obraz własnego ciała, niechęć przyjmowania posiłków) i wywiad były jednak na tyle charakterystyczne, że pozwalały pierwotnie ustalić rozpoznanie AN. OCD natomiast należy różnicować z zaburzeniami lękowymi, zaburzeniami odżywiania, w szczególności AN, zaburzeniami depresyjnymi, cielesnymi zaburzeniami dysmorficznymi, zaburzeniami ze spektrum autyzmu, uzależnieniami, zaburzeniami psychotycznymi, tikami oraz zespołem Touretta.

Należy podkreślić fakt, że w różnicowaniu OCD wymienia się AN, stąd mogły pojawić się problemy z ustale- 
could be the source of difficulties in the diagnostic process and initial diagnosis of $\mathrm{AN}$ (recognised as an expression of OCD in the further course of therapy). The patient's symptoms indicating OCD were hours-long beautifying rituals, repeating the activities, perfectionism in doing her homework, excessive accuracy, correcting her notes, and immoderate looking in the mirror [15].

The symptoms of OCD and AN occurred simultaneously or in close time proximity in the patient. In terms of comorbidity of the abovementioned conditions, OCD with the dominance of compulsive behaviours is observed more often, of which the patient is an example [8]. This case proves that the disorders are strongly linked.

At a certain point in the course of therapy, schizotypal personality disorder (SPD) was suspected due to bizarre behaviours, unnatural facial expressions, inadequate gestures, and social isolation, i.e. the symptoms included in the diagnostic criteria for this disorder according to ICD-10. SPD is often observed in patients with OCD. About $1-10 \%$ of patients with OCD is diagnosed with SPD, which is a predictor of poor outcome of treatment. This diagnosis was not confirmed in the patient referred to above. However, she was diagnosed with personality disorder not otherwise specified (F60.9).

Among other personality disorders diagnosed in patients with OCD are borderline (5\%), avoidant (5-15\%), and dependent $(7.6 \%)[9,10]$.

It is worth paying attention to the patient's family situation. It has been proven that depression in mothers of schoolchildren can lead to deterioration of their adapting skills, internalisation or externalisation, affect, anxiety, and behaviour disorders [11]. It has been also documented that in divorced families, children have more behaviour disorders in comparison to their peers who did not experience their parents' divorce. Parents' separation can have both short- and long-term effects on the child's behaviour. After a divorce, the mother can develop disorders manifesting as decreased sensitivity and greater tendencies towards depression [12].

Taking into account the ambiguous nature of the patient's disorder and the complicated diagnostic process, different forms of therapy had to be applied, including cognitive-behavioural therapy (CBT) in the form of individual and group therapy, family therapy, canine-assisted therapy, cinema therapy, and pharmacotherapy. Some of them have proven to be effective in both OCD and AN while others are directed specifically towards one disorder.

CBT has a documented positive influence on OCD and $\mathrm{AN}$ and therefore is recommended as a form of treatment in both of these conditions $[13,14]$. It is a structured method of therapy whose specific goal is to imple- niem rozpoznania u pacjentki i początkowe stwierdzenie AN, która w późniejszym procesie diagnostycznym została uznana za wyraz OCD. Objawy występujące u nastolatki wskazujące na OCD to wielogodzinne rytuały pielęgnacyjne, powtarzanie pewnych czynności, perfekcjonizm w wykonywaniu zadań szkolnych, nadmierna dokładność, poprawianie notatek, przeglądanie się w lustrach [15].

U pacjentki objawy OCD oraz AN wystąily jednocześnie lub w niedużym odstępie czasu. W przypadku współwystępowania powyższych schorzeń częściej obserwuje się OCD z przewagą zachowań kompulsyjnych, co zaobserwowano u opisywanej pacjentki [8]. Jest to przykład potwierdzający tezę, że występowanie tych zaburzeń jest ze sobą silnie powiązane.

Na pewnym etapie leczenia u pacjentki wysunięto podejrzenie schizotypowych zaburzeń osobowości (SPD), ze względu na dziwaczne zachowania, nienaturalną mimikę twarzy, niedostosowane gesty, izolację społeczną, które zawierają się $\mathrm{w}$ kryteriach rozpoznania tego zaburzenia według ICD-10. Schizotypowe zaburzenia osobowości są często obserwowane w OCD - około 1-10\% pacjentów z OCD ma rozpoznaną SPD, jednocześnie są predyktorem słabych wyników leczenia. U opisywanej pacjentki to rozpoznanie ostatecznie nie zostało potwierdzone, natomiast stwierdzono zaburzenie osobowości bliżej nieokreślone (F60.9).

Wśród innych zaburzeń osobowości stwierdzanych u pacjentów z OCD warto zwrócić uwagę na zaburzenie typu borderline (u 5\%), unikające (u 5-15\%) oraz zależne $(7,6 \%)[9,10]$.

Warto zwrócić także uwagę na system rodzinny pacjentki. Wykazano, że konsekwencjami depresji u matki dzieci $\mathrm{w}$ wieku szkolnym mogą być pogorszone zdolności adaptacyjne, internalizacja lub eksternalizacja, zaburzenia afektu, zaburzenia lękowe i zaburzenia zachowania [11]. Udokumentowano również, że w rozwiedzionych rodzinach dzieci mają więcej zaburzeń zachowania $\mathrm{w}$ porównaniu $\mathrm{z}$ rówieśnikami, którzy nie doświadczyli rozwodu rodziców. Rozwód wpływa zarówno krótko-, jak i długoterminowo na zachowanie dziecka. Po rozwodzie pojawiają się także zaburzenia u matek, które wykazują się mniejszą wrażliwością i większymi skłonnościami depresyjnymi [12].

Ze względu na niejednoznaczny obraz choroby oraz skomplikowany proces diagnostyczny u pacjentki stosowano różne formy terapii, wśród których można wymienić terapię kognitywno-behawioralną (CBT) w formie indywidualnej i grupowej, terapię rodzin, dogoterapię, filmoterapię oraz farmakoterapię. Niektóre z nich mają udowodnioną skuteczność zarówno w OCD, jak i AN, a inne są ukierunkowane specyficznie na jedno $z$ tych zaburzeń.

W obu tych jednostkach chorobowych zaleca się stosowanie CBT, której skuteczność została udokumentowana $[13,14]$. Jest to usystematyzowana forma terapii, która posiada konkretny cel w postaci wprowadzenia korzyst- 
ment beneficial changes in the patient's thought process and behaviour, and improve the quality of their life.

Exposure and response prevention (ERP) is a specific form of CBT used as the treatment of choice in OCD. The patient is exposed to different cues that trigger their anxiety or a certain ritual. Their task is to attempt to contain their obsessions and compulsions. In the course of therapy, such techniques as exposure in vivo, imaginal exposure, ritual prevention, and processing are suggested. Exposition in vivo consists in exposition gradation, i.e. gradual increase in the cue's intensity to the extent tolerated by the patient. Objects, words, images, or situations can be used as cues. The choice of the cue or their combination depends on the patient's individual obsessions and compulsions. During imaginal exposure, the patient is asked to imagine a distressing situation and the consequences of failing to fulfil their ritual. In the next step, the patient is instructed to cease performing a certain task. The final step involves a conversation between the patient and their therapist during and following the exposure. The conversation focuses on the analysis of how the experience confirms or denies the patient's idea of it. Results of many studies show that ERP is effective at reducing OCD symptoms during and following therapy. Furthermore, implementing ERP as an addition to pharmacotherapy increases its efficacy $[13,15]$.

Attending group therapy with others suffering from similar disorders allows the patient to acknowledge that they are not isolated in experiencing their symptoms and feelings. A community may give the patient the feeling of acceptance and belonging. This therapy assumes that its participants can use the skills they acquired outside of the therapeutic group. They include improved interpersonal skills, the ability to form relationships, and the ability to cope with stress. Thanks to them, the patient can return to normal functioning in the society [16]. The therapy might be applied both in OCD and AN $[15,17]$.

It is extremely difficult to understand the problems and symptoms of adolescents without taking into account their family background. Therefore, family therapy is an excellent tool in the course of treatment of AN. The patient's family and housemates are invited to therapy to observe and understand the underlying patterns of their relationships. There is a special type of therapy for patients suffering from anorexia which is divided into 4 phases. The whole family takes part in the first phase, which consists of a few sessions. Attention is paid to the patient's symptoms, and their family's feelings associated with their disorder. Externalising techniques are applied to reveal the external character of AN. In case of symptomatic improvement, the therapy is continued in the second phase in which the previously applied techniques are supplemented by intergenerational nych zmian w sposobie myślenia pacjenta i zachowania oraz polepszenia jakości jego życia.

Szczególną postacią terapii CBT jest terapia ekspozycji i powstrzymania reakcji (ERP), będąca leczeniem pierwszego wyboru w OCD. Pacjenta eksponuje się na bodźce, które rodzą w nim lęk lub wyzwalają wykonanie konkretnego rytuału, a jego zadaniem jest próba powstrzymania obsesji i kompulsji. W przebiegu tej terapii można zastosować takie techniki, jak ekspozycja jawna i ekspozycja wyimaginowana, prewencja rytuału oraz przetwarzanie doświadczeń. Ekspozycja jawna stosuje gradację ekspozycji, co oznacza stopniowe zwiększanie bodźca tak, aby pacjent tolerował go w coraz większym nasileniu. Bodźcami takimi mogą być przedmioty, słowa, obrazy czy sytuacje. Wybór jednego z tych środków (lub ich połączenie) jest uzależniony od przedmiotu obsesji i kompulsji pacjenta. Podczas ekspozycji wyimaginowanej pacjent jest proszony o wyobrażenie sobie sytuacji, która jest dla niego niepokojąca, i konsekwencji zaniechania wykonania rytuału. Wiąże się to z kolejnym etapem, podczas którego terapeuta instruuje pacjenta, aby powstrzymał się od wykonania danej czynności. Ostatnim elementem jest rozmowa w trakcie oraz po ekspozycji, podczas której omawia się, jak dana sytuacja potwierdza lub podważa oczekiwania pacjenta co do konsekwencji zaniechania rytuału. Wyniki wielu badań wskazują, że ERP jest skuteczne w redukcji objawów OCD, także po zakończeniu terapii. Ponadto stwierdzono, że zastosowanie ERP jako dodatku do farmakoterapii zwiększa jej skuteczność $[13,15]$.

Udział $\mathrm{w}$ terapii grupowej, która także jest rodzajem CBT, z innymi osobami cierpiącymi na podobne zaburzenia pozwala na uświadomienie sobie, że nie jest się odosobnionym w doświadczaniu objawów i uczuciach $\mathrm{z}$ nimi związanymi. Pozwala to na stworzenie wspólnoty, która daje poczucie akceptacji i przynależności. Założeniem jest, że umiejętności nabyte w czasie terapii zostaną przeniesione poza grupę terapeutyczną. Wśród tych zdolności można wymienić bardziej rozwinięte umiejętności interpersonalne, umiejętności tworzenia relacji, sposoby radzenia sobie ze stresem, dzięki czemu pacjent może z czasem powrócić do normalnego funkcjonowania w społeczeństwie [16]. Ta forma terapii jest stosowana zarówno w OCD, jak i AN [15, 17].

Argumentem do stosowania terapii rodzin $\mathrm{w}$ AN jest fakt, że niezwykle trudno jest zrozumieć problemy i objawy osób w okresie dojrzewania, nie uwzględniając systemu rodzinnego. $Z$ tego względu zaprasza się rodzinę i wszystkie osoby mieszkające $\mathrm{z}$ pacjentem, aby zaobserwować i zrozumieć wzorce ich relacji. Istnieje specjalny rodzaj tej terapii dla pacjentów cierpiących na anoreksję, podzielony na cztery fazy. W pierwszej fazie, składającej się z kilku sesji, uczestniczy cała rodzina. Uwagę poświęca się objawom pacjentki/pacjenta, uczuciom, jakie przeżywa rodzina w związku z jego/jej chorobą, stosuje się techniki eksternalizacji problemu, co ma na celu uwidocznienie zewnętrznego wymiaru AN. Po osiągnięciu 
communication. In the third phase, separate sessions for the patient and their parents are introduced (the therapy is carried out in subsystems). The patient sessions are oriented towards improving their self-esteem, the image of their own body, and control over their lives as well as understanding the underlying mechanisms of the disorder and factors affecting it. The parent sessions focus on improving the relationships with one another. In the final stage of the therapy, future plans for the patient and the whole family are made. If necessary, individual therapy is continued. The research proves the effectiveness of family therapy in the course of the treatment of adolescent females suffering from AN [15].

Canine assisted therapy is another adjuvant form of therapy that has a positive impact on the treatment of internalisation disorders, including AN and OCD. It positively influences social behaviours and improves the global functioning of the patient [18].

Cinema therapy, falling under occupational therapy, is a complementary technique of psychotherapeutic influence. The use of movies in the course of therapy allows the patient to identify with its characters and cope with difficult situations [19].

It should be noted that the early phase of the treatment relied on sertraline, which is a drug used in both disorders (AN and OCD). The therapy resulted in alleviation of AN symptoms but was not successful in controlling OCD. In the further course of the treatment, fluoxetine was used in pharmacotherapy. It could be implemented because the patient regained the appropriate body mass [1]. Improvement in the state of the patient's health was observed.

The above case shows that OCD is a disease of a very complex aetiology and a chronic course. Nonetheless, appropriate recognition and treatment make it possible to control it and allow patients to function in the society. The focus on anorexia in the diagnostic process can distract from the underlying disorder (OCD in this case). poprawy objawowej następuje drugi etap, na którym kontynuuje się wcześniej podjęte działania i rozpoczyna się pracę nad sposobem komunikacji międzypokoleniowej. $\mathrm{W}$ trzeciej fazie wprowadza się oddzielne sesje dla pacjentki/pacjenta i rodziców (terapia przebiega w podsystemach). W przypadku opisywanej pacjentki miały one na celu poprawę poczucia własnej wartości, obrazu własnej osoby, wpływu na własne życie, zrozumienia mechanizmów choroby i czynników mających na nią wpływ, a dla rodziców - ukierunkowane były na poprawę relacji między nimi. W końcowej fazie terapii tworzone są plany na przyszłość dotyczące pacjentki/pacjenta oraz całej rodziny, ewentualnie kontynuuje się terapię indywidualną. Wyniki badań potwierdzają skuteczność terapii rodzin w leczeniu AN u dziewcząt w wieku nastoletnim [15].

Dogoterapia również stanowi technikę wspomagającą standardową terapię, mającą pozytywny wpływ na leczenie zaburzeń internalizacyjnych, do których należą AN oraz OCD. $Z$ dobrym skutkiem oddziałuje na zachowania społeczne i poprawia ogólne funkcjonowanie pacjenta [18].

Filmoterapia, będąca jednym $\mathrm{z}$ rodzajów terapii zajęciowej, jest uzupełniającą techniką oddziaływania psychoterapeutycznego. Wykorzystanie obrazów filmowych $\mathrm{w}$ toku terapii umożliwia pacjentowi identyfikowanie się $\mathrm{z}$ bohaterami i dzięki temu radzenie sobie $\mathrm{z}$ trudnymi sytuacjami [19].

Odnotować należy, że u pacjentki początkowa faza leczenia opierała się na sertralinie, która jest lekiem stosowanym w obu zaburzeniach (AN i OCD). Terapia ta przyczyniła się do ustąpienia objawów AN, lecz nie dawała zadowalających efektów w kontrolowaniu OCD. $\mathrm{W}$ dalszym przebiegu leczenia zmieniono farmakoterapię na fluoksetynę, która mogła zostać wdrożona ze względu na osiągnięcie prawidłowej masy ciała przez pacjentkę [1]. Zaobserwowano poprawę stanu zdrowia.

Jak widać w powyższym przypadku OCD są schorzeniami o bardzo złożonej etiologii i przewlekłym przebiegu. Niemniej jednak prawidłowe rozpoznanie i terapia umożliwiają ich kontrolę oraz pozwalają na funkcjonowanie pacjentów w społeczeństwie. Skupiając się na anoreksji w procesie diagnozy, można pominąć leżące u podstaw zaburzenie, jakim w tym wypadku było OCD. 


\section{References/Piśmiennictwo}

1. Wciórka J, Pużyński S, Rybakowski J. Psychiatria - podstawy psychiatrii. Tom 2. Wyd. II. Wrocław: Edra Urban \& Partner; 2012.

2. Gałecki P, Szulc A. Psychiatria. Wrocław: Edra Urban \& Partner; 2018.

3. Simpson HB, Stein MB, Hermann R. Obsessive-Compulsive Disorder in Adults: Epidemiology, Pathogenesis, Clinical Manifestations, Course, and Diagnosis. In: Post TW (ed.). Waltham, MA: UpToDate. Available at: https://www.uptodate.com/contents/obsessive-compulsive-disorder-in-adults-epidemiology-pathogenesis-clinical-manifestations-course-and-diagnosis (Accessed: 8.01.2021).

4. Yilmaz Z, Halvorsen M, Bryois J, Yu D, Thornton LM, Zerwas S, et al. Examination of the shared genetic basis of anorexia nervosa and obsessive-compulsive disorder. Mol Psychiatry 2020; 25: 2036-2046.

5. Bang L, Kristensen UB, Wisting L, Stedal K, Garte M, Minde Å, Rø Ø. Presence of eating disorder symptoms in patients with obsessive-compulsive disorder. BMC Psychiatry 2020; 20: 36.

6. Błachno M, Bryńska A. Współwystępowanie i charakter objawów obsesyjno-kompulsyjnych w jadłowstręcie psychicznym [Comorbidity and characteristic of obsessive-compulsive symptoms in anorexia nervosa]. Psychiatr Pol 2012; 46: 1019-1028.

7. Rothenberg A. Adolescence and eating disorder: the obsessive-compulsive syndrome. Psychiatr Clin North Am 1990; 13: 469-488.

8. Levinson CA, Zerwas SC, Brosof LC, Thornton LM, Strober M, Pivarunas B, et al. Associations between dimensions of anorexia nervosa and obsessive-compulsive disorder: An examination of personality and psychological factors in patients with anorexia nervosa. Eur Eat Disord Rev 2019; 27: 161-172.

9. Attademo L, Bernardini F. Schizotypal personality disorder in clinical obsessive-compulsive disorder samples: a brief overview. CNS Spectr 2020. DOI: 10.1017/S1092852920001716.

10. Thamby A, Khanna S. The role of personality disorders in obsessive-compulsive disorder. Indian J Psychiatry 2019; 61 (Suppl 1): S114-S118.

11. Cummings EM, Davies PT. Maternal depression and child development. J Child Psychol Psychiatry 1994; 35 : 73-112.

12. Weaver JM, Schofield TJ. Mediation and moderation of divorce effects on children's behavior problems. J Fam Psychol 2015; 29: 39-48.

13. Foa EB. Cognitive behavioral therapy of obsessive-compulsive disorder. Dialogues Clin Neurosci 2010; 12: 199207.

14. Murphy R, Straebler S, Cooper Z, Fairburn CG. Cognitive behavioral therapy for eating disorders. Psychiatr Clin North Am 2010; 33: 611-627.

15. Namysłowska I. Psychiatria dzieci i młodzieży. Wyd. II. Warszawa: PZWL; 2016.

16. Malhotra A, Baker J. Group Therapy. In: StatPearls. Treasure Island (FL): StatPearls Publishing. Available at: https://www.ncbi.nlm.nih.gov/books/NBK549812/?fbclid=IwAR1VrCrLAHHrCyW1QCd_47dJlcdQukcaNbhJjqmvw5eVSKmiMISU54HZK6s (Accessed: 19.04.2021).

17. Jónsson H, Hougaard E. Group cognitive behavioural therapy for obsessive-compulsive disorder: a systematic review and meta-analysis. Acta Psychiatr Scand 2009; 119: 98-106.

18. Jones MG, Rice SM, Cotton SM. Incorporating animal-assisted therapy in mental health treatments for adolescents: a systematic review of canine assisted psychotherapy. PLoS One 2019; 14: e0210761.

19. Mekhakyan A, Szulc A, Imielski W. Film as a psychotherapeutic tool. Selected problems of filmotherapy. Psychiatria 2018; 15: 127-134. 